\title{
SPV based water pumping system for an academic institution
}

\author{
Majid Jamil ${ }^{1}$, Ahmed Sharique Anees ${ }^{1}$, M. Rizwan ${ }^{2, *}$ \\ ${ }^{1}$ Department of Electrical Engineering, Jamia Millia Islamia, New Delhi, India \\ ${ }^{2}$ Department of Electrical Engineering, Delhi Technological University, Delhi, India
}

\section{Email address:}

rizwaniit@yahoo.co.in (M. Rizwan), shariq.anees@gmail.com (Ahmed Sharique Anees)

\section{To cite this article:}

Majid Jamil, Ahmed Sharique Anees, M. Rizwan. SPV Based Water Pumping System for an Academic Institution, American Journal of Electrical Power and Energy Systems. Vol. 1, No. 1, 2012, pp. 1-7. doi: 10.11648/j.epes.20120101.11

\begin{abstract}
This paper presents the water pumping system based on solar photovoltaic (SPV) to cater the need of water in an academic institution for various applications like irrigation, drinking, washing etc. In this paper a case study of Faculty of Engineering and Technology (FET), Jamia Millia Islamia, New Delhi, India is carried out. Presently water is pumped with the help of grid power supply resulting huge energy consumption. As solar water pumping has several advantages over conventional water pumping systems, apart from economical advantages, therefore an attempt has been made to develop SPV based water pumping system to meet daily water needs of the institute. A techno-economic analysis of SPV based water pumping system and comparison of proposed system with the conventional one is also discussed in this work.
\end{abstract}

Keywords: SPV System; Water Pumping System; Decentralized Application; Environmental Benefit

\section{Introduction}

Photovoltaic pumping systems provide a welcome alternative to grid power supply based water pumping systems or hand pumps. They provide the most water precisely when it is needed the most that is when the sun shines the brightest. The generation of solar electricity coincides with the normal peak demand during daylight hours in most places, thus justifying peak energy costs, brings total energy bills down, and obviates the need to build as much additional generation and transmission capacity as would be the case without PV Solar pumps. Advantages of using PV-powered pumps include low maintenance, ease of installation, reliability and scalability. A SPV water pumping system consist of a DC / AC surface mounted / submersible / floating motor pump set, electronics if any, interconnect cables, a on-off switch and a PV array mounted on a suitable structure with a provision of tracking. A SPV water pumping system is expected to deliver a minimum of 65000 liters per day for a 900 watts panel and 135000 liters per day for an 1800 watts panel from a suction head of 7 meters and total head of 10 meters on a clear sunny day. In case of deep well submersible pumps, the water shall be a minimum of 45000 liters from $1200 \mathrm{Wp}$. The discharge from the pump would vary with the intensity of the sunrays from morning till evening. India being a tropical country receives adequate solar radiation for 300 days, amounting to 3,000 hours of sunshine equivalent to over 5,000 trillion $\mathrm{kWh}$. Almost all the regions in India receive 4-7 $\mathrm{kWh}$ of solar daily radiation per sq meters depending upon the location. In India there is an acute shortage of power. The per capita annual energy consumption of the country is hardly $779 \mathrm{kWh}$ whereas world average is 2600 $\mathrm{kWh}$. During last decade, a lot of industrialization took place in the country but growth suffered due to lack of power [1]-[2]. To bridging the gap between demand and supply, use of renewable resources is becoming important keeping in mind the environmental benefits. Major types of renewable energy sources include solar, wind, hydro and biomass, all of which have huge potential in India to meet future energy challenges. Solar power is one of the most promising and more predictable than other renewable sources and less vulnerable to changes in seasonal weather. Generation of power from other renewable sources is limited to sites where these resources exist in sufficient quantities whereas solar energy can produce power at the point of demand in both rural and urban areas [3].

A review of solar water pumping systems is presented for Palestine [4]. Feasibility analysis is carried out for solar water pumping systems. In this paper the water pumping system is proposed at low cost. In addition, the information about the conventional pumps is also presented.

$\mathrm{PV}$ water pumping systems for energy conservation is also presented [5]. Two pumps of $7.5 \mathrm{~kW}$ total $15 \mathrm{~kW}$ were replaced by solar PV pump to lift the water. Operating the PV pump for only 10 hours in a day yielded a net saving of 
3000 units which is $7.5 \%$ of the total consumption of 40000 units in an industry. However, the solar PV pumps are expensive but the cost would be reduced in near future.

An experimental agricultural structure has been implemented to overcome factors affecting the valorization of new technologies for irrigation in dry season such as the lack of modern technological knowledge by farmers, the lack of affordable means by farmers, the lack of interface between the researchers and the users of research results [6]. Convincing results revealed that the farmers could afford to invest in the photovoltaic water pumping projects for irrigation, the incomes being better than the ones in raining season.

Several types of pumps and motors are available in the market based on the PV pumping [7]-[8]. The commonly employed pumps are the single-stage centrifugal and helical rotor type. The most commonly utilized motor for PV pumping systems is the permanent magnet (PM) brush less direct current (BLDC) motor. However, induction motors and brushless dc motors are generally used in bore-hole and deep well pumping applications because of less maintenance. Since BLDC consumes less power in comparison with induction motor therefore it is preferred in SPV based water pumping system [9]. In addition there is no requirement of inverter assembly in BLDC based SPV system. In this paper, a techno-economic analysis of SPV based water pumping system is proposed and compared with the existing system.

The proposed study is carried for an academic institute at faculty of engineering and technology, Jamia Millia Islamia, New Delhi, India, having more than 5000 students and employs at the campus daily. Heavy payments towards electricity bills and shortage of power resulting power cuts for many hours in a day particularly during peak seasons encouraged to provide an alternative option to replace the grid operated pumping system with the SPV based pumping system to ensure reliable, economical and environment friendly supply. The paper is organized as follows: Section 2 presents the brief description of existing water pumping systems. A design analysis of the proposed system based on $\mathrm{AC}$ drive and DC drive is discussed in Section 3 and Section 4 respectively. Techno-economic analysis of the proposed system is discussed in Section 5. Results and discussions are presented in Section 6. A conclusions followed by the references is presented in Section 7.

\section{Description of Existing AC Drive}

Table 1. Ratings of various pumps and their duration of operation.

\begin{tabular}{|c|c|c|c|c|c|}
\hline S. No. & Items & Ratings in HP & Total time of Operation & Duration of Operation & Purpose \\
\hline 1 & Submersible Pump 1 & 7.5 & $7 \mathrm{hr}$. & $\begin{array}{l}\text { 9:00 AM to } 1: 00 \mathrm{PM} \\
\text { 3:00 PM to } 6: 00 \mathrm{PM}\end{array}$ & $\begin{array}{l}\text { Lifts the water from underground } \\
\text { to circular tank }\end{array}$ \\
\hline 2 & Submersible Pump 2 & 10 & $5 \mathrm{hr}$. & $\begin{array}{l}\text { 9:00 AM to } 12: 00 \mathrm{PM} \\
\text { 3:00 PM to 5:00 PM }\end{array}$ & $\begin{array}{l}\text { Supply water } \\
\text { from circular tank to different } \\
\text { buildings }\end{array}$ \\
\hline 3 & Booster Pump 1 & 10 & $3 \mathrm{hr}$. & 9:00 AM to $12: 00 \mathrm{PM}$ & Irrigation \\
\hline
\end{tabular}

The existing water pumping system of the proposed site supply water to many neighbouring buildings of the campus such as faculty of engineering building, dean's office, canteen, faculty of architecture, department of management, faculty of third world studies and many parks located in the premises. The total water requirement of proposed site is around 1.1 million litres per day. Out of which 50,000 litters are used in wash rooms, 10000 litres for drinking and 50000 litres for irrigation. To fulfil this requirement, the existing system comprises one water pumping station which consists of various electric water pumps like submersible pump, induction motor type pump. These pumps lift the water from the ground to the overhead tanks placed on the top of the buildings.

As mentioned above, the daily water requirements for irrigation at FET premises is 50,000 litters. To meet this demand, two booster pumps of $10 \mathrm{HP}$ each are installed. These motor-pump are operating for 5 hours daily. Water is supplied from the round tank which is situated nearby the pumping station to the lawns of the campus at a horizontal distance of around 400 meters from pumping station. Another important requirement of water is in washrooms that is around 50,000 litters per day. Since availability of water in washrooms is essential all twenty four hours, therefore facility of water storage is required. One circular storage tank of the capacity 40000 liters placed on the ground level is provided to store water and it is pumped through one $10 \mathrm{HP}$ submersible pump, extracting water from 100 feet below the ground level. Further the water is also pumped to 8 neighboring buildings of the campus by another 10 HP pump. Maximum horizontal and vertical distances from the water tank placed on the ground to the overhead tanks placed on the roof top of different buildings are 300 meters and 25 meters respectively.

To meet drinking water needs of around 10000 litres per day a water tank of one lack litre capacity is provided at ground level. Further, the water is pumped to overhead tanks by two induction motors of $5 \mathrm{HP}$ each. These motors are operated for one hour per day for the aforesaid application.

The details of different motors operation used in the existing system are presented in Table 1 and the description of storage tanks are presented in Table 2. 


\begin{tabular}{llcccl}
\hline S. No. & Items & Ratings in HP & Total time of Operation & Duration of Operation & Purpose \\
\hline 4 & Booster Pump 2 & 10 & $2 \mathrm{hr}$ & $3: 00$ PM to 5:00 PM & Irrigation \\
\hline 5 & Pump 1 & 5 & $1 \mathrm{hr}$ & $8: 00$ AM to 9:00 AM & $\begin{array}{l}\text { Supply the MCD water from rec- } \\
\text { tangular tank to different buildings }\end{array}$ \\
6 & Pump 2 & 5 & $1 \mathrm{hr}$. & $8: 00$ AM to 9:00 AM & $\begin{array}{l}\text { Supply the MCD water from rec- } \\
\text { tangular tank to different buildings }\end{array}$ \\
\hline
\end{tabular}

Table 2. Description of various storage tanks.

\begin{tabular}{|c|c|c|c|c|}
\hline S.No. & Description & Size $(L * B * D)$ in $\mathbf{f t}$ & Tank size $\left(\mathbf{f t}^{3}\right)$ & Tank capacity in Litres \\
\hline 1. & MCD rectangular Tank & $22.5 * 16.5 * 10$ & 3712.5 & 105000 \\
\hline 2. & Ground water circular tank & 12.7 Diameter, Depth 12 & 1519.3518 & 43000 \\
\hline 3. & Over head tank on each building & & & 100000 \\
\hline
\end{tabular}

The block diagram of existing pumping system is shown in Figure 1.

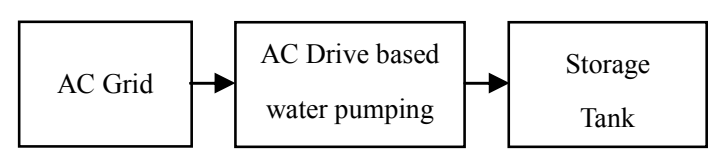

Figure 1. AC Driven based grid connected water pumping system.

\section{SPV Based Water Pumping System}

In the proposed study two options are suggested based on solar power generation. One is AC driven motor pump set feed from SPV plant and the other is DC drive based SPV array connected water pumping system. Here technical and economical feasibility of both options are discussed and compared with the existing system.

\subsection{AC Driven Based SPV Plant Connected Water \\ Pumping System}

Here existing motor pump set is used to pump the water. Only grid power is replaced by solar power. The block diagram of proposed AC driven based SPV water pumping system is shown in Figure 2.

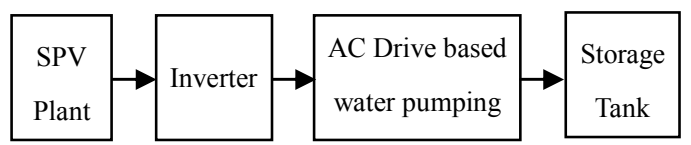

Figure 2. AC driven based SPV array connected water pumping system.

\subsection{Drive based SPV Array Connected Water Pumping System}

It is the other option in which existing ac motor-pump sets are replaced by dc motor-pump sets. Here dc generated power from solar system is fed directly to de motor-pump sets eliminating need of converting dc into ac that minimizing the cost. Three different water pump sets are to be installed for different applications to meet the water need.
The description of proposed system is shown in Figure 3.

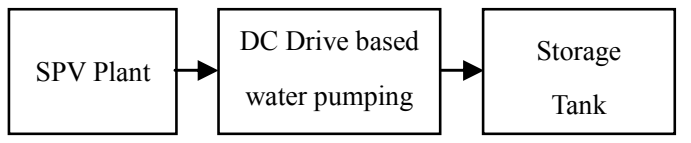

Figure 3. DC drive based SPV array connected water pumping system.

In this scheme, the centrifugal water pump sets are connected with d.c drive based motor. The power generated by $\mathrm{PV}$ array is feed to dc motors as shown in Figure 4 [7]. For each pump set separate solar array is provided. A separate boring is also required at nearby place for this system. In SPV based water pumping system a 2 pole brush less synchronous DC motor for driving the centrifugal pump is used. A layout of the proposed system is shown in Figure 4.

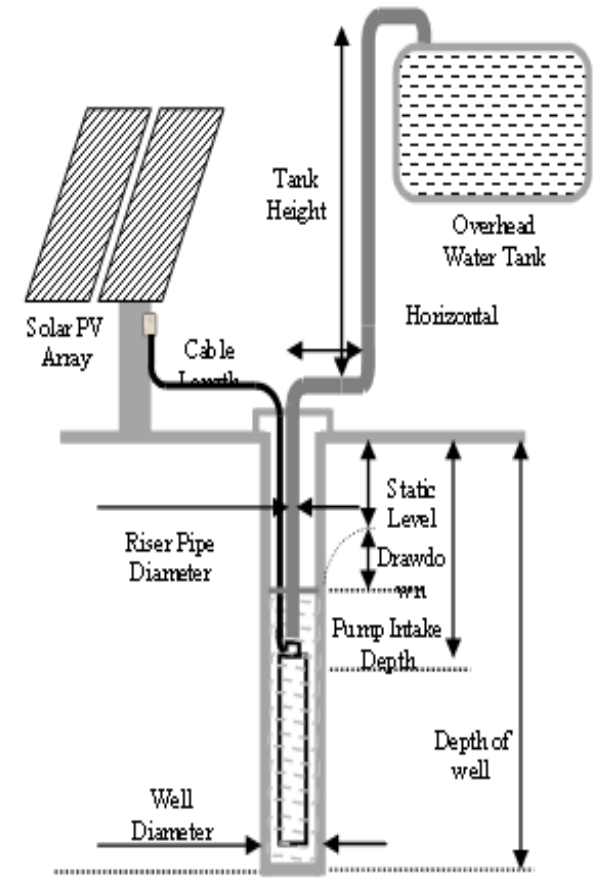

Figure 4. Layout of the proposed system. 


\section{Techno-Economic Analysis}

A techno economical analysis of existing and proposed methods is carried out to identify the better and viable option. The better option means the system be reliable, efficient and economical. Further the techno economic analysis is done keeping in view of electricity tariff appreciation in the existing water pumping system and government policies in the proposed SPV based water pumping system.

\subsection{Existing AC Drive based Grid Connected Water Pumping System}

As the existing system does not require any new installation, the running and maintenance cost only is involved. The running and maintenance cost includes electricity bills and maintenance of the system. For calculating the electricity charges, the study of load cycle curve or energy consumption per day is required. Therefore the load curve of the existing water pumping system is drawn and shown in Figure 5. The energy consumption of different pump sets which are used in the existing grid connected water pumping system is presented in Table 3 .

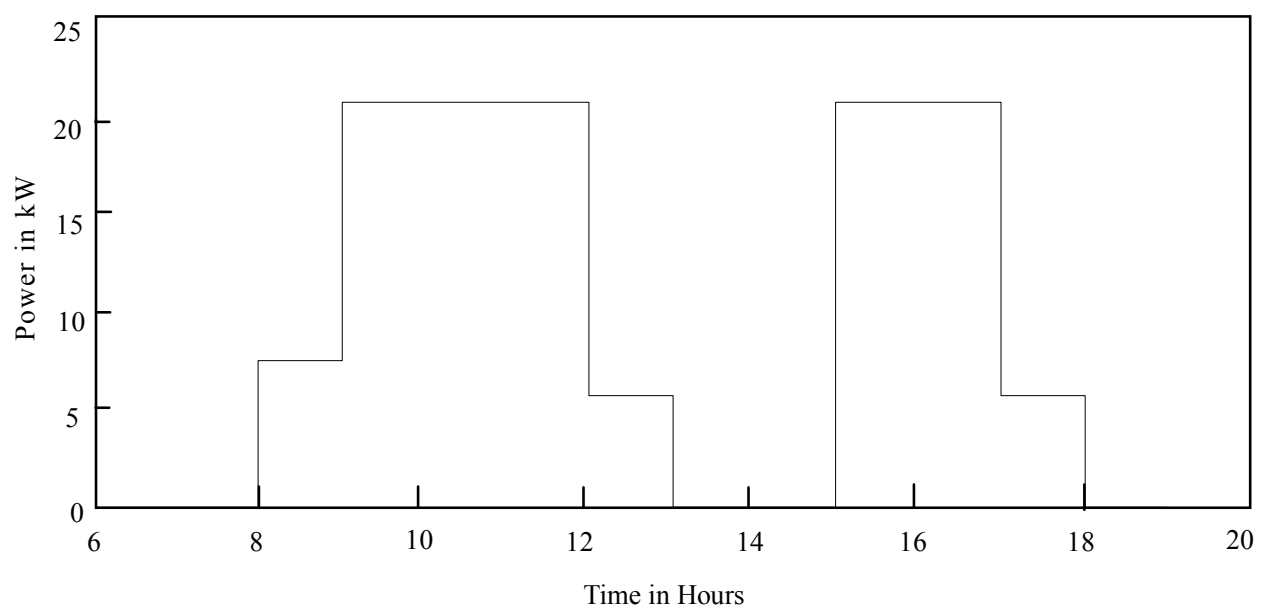

Figure 5. Daily load cycle for the existing water pumping station.

Table 3. Annual energy consumption in the existing system.

\begin{tabular}{|c|c|c|c|c|c|}
\hline S. No. & Items & Ratings in $(\mathbf{k W})$ & $\begin{array}{c}\text { Total time of } \\
\text { Operation (Hours) }\end{array}$ & $\begin{array}{c}\text { Energy Consumed } \\
\text { per Day (kWh) }\end{array}$ & $\begin{array}{c}\text { Energy Consumed per } \\
\text { Year (kWh) }\end{array}$ \\
\hline 1 & Submersible Pump1 & 5.595 & 7 & 39.165 & 14295.225 \\
\hline 2 & Submersible Pump2 & 7.46 & 5 & 37.3 & 13614.5 \\
\hline 3 & Booster Pump1 & 7.46 & 3 & 22.38 & 8168.7 \\
\hline 4 & Booster Pump2 & 7.46 & 2 & 14.92 & 5445.8 \\
\hline 5 & Pump1 & 3.73 & 1 & 3.73 & 1361.45 \\
\hline 6 & Pump2 & 3.73 & 1 & 3.73 & 1361.45 \\
\hline 7 & $\begin{array}{l}\text { Total Electrical Energy } \\
\text { Consumption in } \mathrm{kWh}\end{array}$ & & & 121.225 & 44247.125 \\
\hline
\end{tabular}

For the existing system, sanctioned load of $25 \mathrm{~kW}$ is used for water pumping purposes. This water pumping system is operating at 0.8 power factor lagging. The cost associated with the existing grid connected water pumping system is shown in Table 4 . The cost of electricity is calculated by two different tariff plans. First one is the old tariff plan which was applicable till June 30, 2012 and the second tariff plan that is the recently revised plan applicable from July 1, 2012 [10]. This exercise is done just to show how frequently the cost of electricity is varying even it increased during the 
proposed duration of study. It can be easily seen from the

of the older tariff plan during this period.

Table 4 that the cost of electricity gets increased by 1.5 times

Table 4. Cost of Energy for the existing grid connected water pumping system.

\begin{tabular}{|c|c|c|c|c|c|}
\hline \multirow{2}{*}{ S. No. } & \multirow{2}{*}{ Existing Systems 25 kW@0.8 p.f. } & \multicolumn{2}{|c|}{ Old Tariff Plan } & \multicolumn{2}{|c|}{ New Tariff Plan } \\
\hline & & Tariff Rate@ Rs. & Amount in Rs. & Tariff Rate@ Rs. & Amount in Rs \\
\hline 1. & Fixed Charges & $50 / \mathrm{kW} /$ Month & 15000 & $115 \mathrm{kVA} /$ Month & 34500 \\
\hline 2. & Variable Energy Charges & 4.92/kVAh & 272120 & $7.25 / \mathrm{kVAh}$ & 400990 \\
\hline 3. & Electricity Tax & $5 \%$ & 13600 & $5 \%$ & 20050 \\
\hline 4. & Surcharge on Fuel & $8 \%$ & 21770 & $8 \%$ & 32080 \\
\hline 5. & Total Annual Electricity Bill & & $322490 /-$ & & $487620 /-$ \\
\hline
\end{tabular}

\subsection{AC Drive based SPV Plant Connected Water Pumping System}

In AC drive based system power is fed from SPV plant. The installation cost of this system include only SPV system however same motor pump sets as used with the grid are used. The capacity of SPV system is determined with the help of load duration curve as shown in Figure 5. From Figure 5, it is observed that the peak power requirement for water pumping system is around $21 \mathrm{~kW}$. To meet peak power requirement, an SPV plant of around $35 \mathrm{kWp}$ would be required considering the $60 \%$ capacity factor. Such system would be quite costly and requires huge space for installation. Therefore, the load cycle is adjusted by changing the operating timings of the pumps. The peak load is distributed during the different hours of the day time when solar power is available. The energy requirement for water pumping is $121 \mathrm{kWh}$ per day. To meet this energy requirement of 121 $\mathrm{kWh}, 15.15 \mathrm{~kW}$ plant would be sufficient considering 8 hours sunshine. The modules available in the market are calibrated at an irradiance of $1000 \mathrm{~W} / \mathrm{m}^{2}$ and $25{ }^{\circ} \mathrm{C}$ [11-12]. However the solar insolation received on earth is varying and not available more than $900 \mathrm{~W} / \mathrm{m}^{2}$ with very low irradiance intensity in early morning and evening hours. The solar insolation varies almost in a sinusoidal way. Therefore the power generated from PV modules is less than the rated value. To fulfil the peak power requirement of $15.15 \mathrm{~kW}$, it is required to install a plant of $26.5 \mathrm{kWp}$. Hence by adjusting load cycle the plant capacity of the SPV based plant is reduced from $35 \mathrm{kWp}$ to $26.5 \mathrm{kWp}$ that minimizing the cost. In India, the solar irradiance available is almost same throughout the year during clear sky. However, the water required for irrigation is also reduced in winter therefore, the same water pumping system is sufficient to fulfill the requirements.
Table 5. Cost for the $26.5 \mathrm{~kW}$ SPV based water pumping system.

\begin{tabular}{lllc}
\hline S.No. & $\begin{array}{l}\text { Major Component } \\
\text { of the SPV plant }\end{array}$ & $\begin{array}{l}\text { Unit Rate } \\
\text { in Rupees }\end{array}$ & $\begin{array}{c}\text { Total Cost } \\
\text { in Rupees } \\
\text { (approximate Cost) }\end{array}$ \\
\hline 1 & $\begin{array}{l}\text { Solar PV Array of } \\
26.5 \mathrm{~kW}\end{array}$ & 100 per watt & $27,00,000$ \\
2 & $\begin{array}{l}\text { Inverter of } 15.153 \mathrm{~kW} \\
\text { Installation and }\end{array}$ & 6000 per kW & $1,00,000$ \\
3 & $\begin{array}{l}\text { accessories charge } \\
4 . \quad\end{array}$ & $\begin{array}{l}\text { Total Cost of the } \\
\text { SPV plant }\end{array}$ & $5,00,000$ \\
\hline
\end{tabular}

\subsection{Drive based SPV Array Connected Water Pumping System}

In DC drive based system the power generated from the SPV array is directly used to operate the DC motor pump set. In this scheme modern brushless dc motor based submersible pumps are used which are low power consuming and have higher efficiency as compared to the conventional motor pump sets.

For the same water requirement for different purposes such as irrigation, drinking and utilities, three different DC motor pumps are used. These pumps are to be installed nearby the existing pumping stations. Therefore the additional cost of boring is required. The types of solar water pumps selected to fulfill the water requirements for different applications are presented. The cost involved in DC drive based system is presented in Table 6 .

Table 6. Total Cost of the DC drive based solar water pumping system.

\begin{tabular}{llc}
\hline S. No. & Items & Cost in Rupees \\
\hline 1. & Drinking Water pump set & $1,11,000$ \\
2. & Irrigation Water pump set & $2,17,000$ \\
3. & Utility/Wash Room pump set & $3,02,000$ \\
4. & Installation charge and others & $3,70,000$ \\
& Total cost of Installation & $10,00,000$ \\
\hline
\end{tabular}




\section{Results and Discussion}

In this paper three different options of water pumping system for the given site are discussed. The proposed system is compared with the existing system. The economical benefits of the proposed study are compared with the existing one. Recently in Delhi state tariff is revised by the government and during last three years it has been revised many times and it is increased more than double during past two years. This effect is also considered in the proposed study. According to old tariff plan, the cost of the proposed ac driven based SPV system was recovering in 12 years and the cost associated with dc drive based SPV system would be recovering in less than 4 years. As per the new tariff plan the same will be recovering in 8 years and 2.5 years respectively. Here the cost of electrical energy receiving from grid was assumed constant over the study period of the proposed system, but in actual practice it increased significantly during study period too. Since the cost of energy is a dependent parameter of the international market, therefore the payback period of the initial investment on the proposed system will be reducing further [10].

Now the proposed system based on AC drive has higher initial investment than the proposed DC drive. But there are certain technical drawbacks in the proposed AC drive based system like lower efficiency because of inverter which has their own conversion loss and at the time of starting it draws dangerously high inrush current from the SPV plant. Further, it is important to provide certain back up scheme during the cloudy weather condition, as the output of the proposed system depends on the solar irradiance level. To meet out the water requirement during the cloudy weather, it is either to increase the water storage capacity or some alternate electrical supply arrangements. So large power is required for proposed AC drive based system but for proposed DC drive based system it is required just to install a rectifier unit which convert the grid power from $\mathrm{AC}$ to $\mathrm{DC}$ and this DC power will be directly fed to the proposed DC system. DC drive based system requires only around $4 \mathrm{~kW}$ powers which is quite less as compared to the existing $\mathrm{AC}$ drive based system.

Hence it is concluded that the proposed system based on DC drive is more efficient and cost effective. As the payback period is much less than the total life of the proposed system, so it is highly recommended to install the proposed system based on DC drive. A comparative study of the proposed system with the existing system is presented in Table 7.

Table 7. Comparative study of different water pumping systems.

\begin{tabular}{|c|c|c|c|c|c|}
\hline S. No. & Different methods & $\begin{array}{l}\text { Equipment and } \\
\text { Installation Cost }\end{array}$ & $\begin{array}{l}\text { Running and maintenance } \\
\text { cost for } 1 \text { year }\end{array}$ & $\begin{array}{l}\text { Running and maintenance } \\
\text { cost for } 20 \text { years }\end{array}$ & $\begin{array}{l}\text { Total Investment } \\
\text { For } 20 \text { years } \\
\end{array}$ \\
\hline \multirow{2}{*}{1.} & $\begin{array}{l}\text { Existing AC drive based } \\
\text { grid connected water } \\
\text { pumping system by } \\
\text { Old Tariff plan }\end{array}$ & Already installed & $3,22,000$ & $64,40,000$ & $64,40,000$ \\
\hline & $\begin{array}{l}\text { Existing AC drive } \\
\text { based grid connected } \\
\text { water pumping } \\
\text { system by New Tariff plan }\end{array}$ & Already installed & $4,87,000$ & $97,40,000$ & $97,40,000$ \\
\hline 2. & $\begin{array}{l}\text { AC drivebased SPV } \\
\text { plant connected } \\
\text { water pumping system }\end{array}$ & $33,00,000$ & 25,000 & $5,00,000$ & $38,00,000$ \\
\hline 3. & $\begin{array}{l}\text { DC drive based SPV } \\
\text { array connected } \\
\text { water pumping system }\end{array}$ & $10,00,000$ & 10,000 & $2,00,000$ & $12,00,000$ \\
\hline
\end{tabular}

\section{Conclusions}

In this paper a solar water pumping system is proposed to meet the water requirements of an academic institution. A case study at faculty of engineering and technology, Jamia Millia Islamia, New Delhi is carried out. Techno-economic analysis of SPV based water pumping system is presented and compared with the existing system. Further a comparative study is also carried out between the existing motor pump sets, if fed by SPV systems in place of grid supply and if the complete existing water pumping system is replaced by the proposed one. The installation cost of the proposed system is around Rs 10 lac that would be recovered in less than 4 years. If the life of the proposed system is considered
20 years, then it would supply power at free of cost for 16 years that is huge savings, where institute is paying around Rs 3 lac per year as electricity bill for this purpose which is a substantial amount for an academic institute in a developing country like India. Apart from economical benefits, the proposed system is environment friendly. Likewise, such a system can be utilized to reduce the grid dependency of the existing systems and to make them more cost effective. This system can also be considered as a potential alternative in areas having deficient power or in areas inaccessible to the main supply grid. 


\section{References}

[1] Directorate of Economics \& Statistics (DES), Department of agriculture and cooperation, Ministry of agriculture, Government of India.

[2] S. N. Kaplanis, New methodologies to estimate the hourly global solar radiation: comparison with existing models, Renewable Energy, vol. 31, pp. 781-790, 2006.

[3] M. Rizwan, Majid Jamil and D. P. Kothari, "Solar energy estimation using REST model for PV-ECS based distributed power generating system", Solar Energy Materials \& Solar Cells, vol. 94, pp. 1324-1328, 2010.

[4] Tamer Khatib, " Design of photovoltaic water pumping systems at minimum cost for Palestine: A review", Journal of Applied Sciences, vol. 10, no. 22, pp. 2773-2784, 2010.

[5] V. A. Kulkarni1 and P. K. Katti, "Energy conservation in industries by PV solar pump as renewable energy source", International Journal of wind and Renewable Energy, vol. 1, Issue 1, pp. 44-47, 2011.

[6] M. Kamta and O. Bergossi, "Factors affecting the valorization of photovoltaic water pumping projects for irrigation in the Adamawa Province (Cameroon)", International Scientific Journal for Alternative Energy and Ecology, vol. 62, no. 6, pp. 49-52, 2008.

[7] T. S. Surendra and S. V. V. Subbaraman, "Solar PV water pumping comes of age in India", Twenty-Ninth IEEE Conference on Photovoltaic Specialists, pp. 1485-1488, 19-24, May 2002.

[8] R. E. Katan, V. G. Agelidis and C. V. Nayar, "Performance analysis of a solar water pumping system", International Conference on Power Electronics, Drives and Energy Systems for Industrial Growth, pp. 81 - 87, vol.1, 8-11 Jan 1996.

[9] http://www.lorentz.de/en/products/submersible_solar_pump s/ps1800.html.

[10] Delhi Electricity regulatory commission. http://www.derc.gov.in/ordersPetitions/orders/Tariff/Tariff\% 20Order/201213/Press\%20Release 26.06.2012/BRPL.pdf.

[11] A. Mukherji, Photovoltaic Analysis and Design, PHI publication, New Delhi,2011.

[12] B. H. Khan, Non Conventional Energy Resources, 2nd edition, Tata McGraw-Hill pg no. 424. 